\title{
DIGESTION OF HIGH FIBER DIET IN SHEEP AND GOAT OF JENEPPONTO
}

\author{
D. P. Rahardja, V.S. Lestari and M. Hatta \\ Faculty of Animal Agriculture, Hasanuddin University \\ Jl. Perintis Kemerdekaan Km.10, Tamalanrea, \\ Makassar (90245), South Sulawesi - Indonesia \\ Correspondinge-mail :djoniprawira@yahoo.com
}

Received July 12, 2010; Accepted August 29, 2010

\begin{abstract}
Four does (goat, G) and four ewes (sheep, S) of Jeneponto were fed chaffed rice straw hay $(3.7 \%$ crude protein, $63.5 \%$ cell wall constituents, $44.5 \%$ acid detergent fiber and $6.2 \%$ acid detergent lignin, all based on dry matter). The intakes and digestibility of the diet by $\mathrm{G}$ and $\mathrm{S}$ were compared. Both species consumed the same level of the diet. G digested dry matter, organic matter, crude protein, crude fiber, and lignin of the diet to a significant higher extent than did by S. The superiority of G over $\mathrm{S}$ in digesting the diet was attributable with longer retention time of ruminal fluid and particulate matters in the rumen and the entire gut, which then resulted in higher proportion of small size particles $(<1 \mathrm{~mm}$ sieve), higher proportions of propionic, butyric, valeric and isovaleric acid concentrations produced in the rumen. Additionally for further studies, there were some possibilities of $\mathrm{G}$ having a better chewing activity (duration and intensity), and ability to maintain higher rumen ammonia levels by a greater urea recycle to the rumen, particularly through salivation.
\end{abstract}

Keywords: sheep, goat, rice straw, digesta retention time, volatile fatty acid

\section{INTRODUCTION}

Sheep and goats are two species of small ruminant reared by small farmer holder in Jeneponto which famous as the hottest and driest regency in South Sulawesi. Apparently, these both species had well adapted in this hars condition.

Goat have the ability to be productive on what would be sub-standard level of nutrition for other ruminants, which is probably due in part to selective feeding habits of goat (Focant et al., 1986). It has been suggested that the adaptation of goats to poor environments, where feed tend to contain high fiber and low protein, may be due to an enhanced digestive efficiency (Gihad et al., 1980). Efficiency of digestion of highly fibrous diets in goats appears to be superior to that in sheep (Gihad et al., 1980; Brown and Johnson, 1982; Watson and Norton, 1982; Doyle et al., 1984; Howe et al., 1988; Devendra, 1989; Reid et al., 1990; Domingue et al., 1991a). However, this was questioned by Huston et al. (1988), who indicated that differences between species in their abilities may complicate interpretation of responses in voluntary feed intake and digestion processes. Additionally, comparison study between sheep and goats of Jeneponto is still scarse.

The purpose of this experiment was to compare the digestion of rice straw hay as a high fiber diet by sheep (S) and goat $(\mathrm{G})$.

\section{MATERIALS AND METHODS}

\section{Animal, feed and feeding}

Four does (G) and four ewes (S) from Jeneponto-South Sulawesi were used. Their ages varied between 2 and 3 years old, and their body weights were $18.8 \pm 1.0 \mathrm{~kg}$ and $16.7 \pm 1.4 \mathrm{~kg}$ for $\mathrm{S}$ and $\mathrm{G}$ respectively, and differed $(\mathrm{P}<0.01)$ between species. They were non-pregnant and nonlactating, healthy and fitted with rumen canullae. All animals were maintained indoor in individual metabolism cages in a room $\left(22-29^{\circ} \mathrm{C}\right.$ and 60 $70 \%$ RH) throughout the experiment. They accepted urea-molasses block freely and were orally dosed with an anthelminthic shortly after being housed.

As adjustment period, the animals were allowed 1 month for recovering their body conditions post-cannulation in addition to adjust to diet provided .

Data of the feed and water intakes, total faecal and urine outputs were recorded during a 7day period subsequently after the adjustment period for measuring digestibility. Thereafter, days 8 through 10 were used to determine ruminal 
fluid volume, its dynamics, and production of volatile fatty acid (VFA), and days 11 through 14 were used to determine the passage rate of particulate matter.

The animals were fed ad-lib of rice straw (Oriza sativa) hay chopped 2-4 cm length. Feed was given with one sixth of previous daily intake approximation at $2 \mathrm{~h}$ intervals manually from $06.00 \mathrm{am}$ to $06.00 \mathrm{pm}$. The refusals were collected and total intake was recorded daily in the morning. Fresh water was offered ad-lib and the intake was measured daily in the morning.

Chemical composition of the mixed hay offered was (\% of DM) : 92.1\% DM, 91.2\% OM, $3.7 \% \mathrm{CP}, 63.5 \%$ cell wall constituents, $44.5 \%$ ADF, $6.2 \%$ lignin, and it was similar for both species.

Total faecal output were collected daily prior to feeding, a $10 \%$ sample was directly dried in an oven at $80-90^{\circ} \mathrm{C}$ for $2-3 \mathrm{~d}$ to obtain dry matter and water content of the daily faeces.. The daily dried faecal samples were pooled in a sealed plastic bag for later analysis.

Urine output was directly drained from bladder through a bladder catheter (Hydrogel coated foley catheter, Bard Limited, West Sussex, $\mathrm{UK}$ ) into a $2 \mathrm{~L}$ urine bag (Urogard, Terumo Corp., Japan) to which a $15 \mathrm{ml}$ of $\mathrm{H}_{2} \mathrm{SO}_{4}$ was added to acidify the urine. The catheter was removed in the last day of the 7-day collection period. Thereafter, separating faeces and urine outputs were by using urine-faeces separator fixed beneath the cages of each animal.

Samples of feed and faeces were analyzed for : dry matter content by drying to constant weight at $100^{\circ} \mathrm{C}$; organic matter content by ashing the sample overnight at $600^{\circ} \mathrm{C}$; cell wall constituents, acid detergent fiber, and acid detergent lignin by the method of Goering and Van Soest (1970).

\section{Ruminal Fluid Volume, its Dynamics, and Production of Volatile Fatty Acid (VFA)}

Flow rate and volume of ruminal fluid were estimated from the disappearance of CrEDTA (a water-soluble marker ) infused intraruminally as a single pulse dose (Faichney, 1993). The marker of CrEDTA was prepared in accordance with the procedures of Binnersts, et al. (1968). A $100 \mathrm{ml}$ (1681.4 $\mu \mathrm{g} \mathrm{Cr} / \mathrm{ml}$ ) of the marker solution was administered intraruminally into each animal. Fifty $\mathrm{ml}$ of ruminal fluid samples were collected from each animal using a suction strainer (Raun and Burroughs, 1962; $19 \mathrm{~mm}$ diameter; $15 \mathrm{~mm}$ mesh) prior to the pulse dose $(0 \mathrm{~h})$ and $2,4,6,8$, 10,12 and $24 \mathrm{~h}$ after dosing. The ruminal fluidparticulate (digesta) samples were used for measuring VFA, Cr concentrations and particulate size distribution. For VFA analysis, a $10 \mathrm{ml}$ of each ruminal sample was added to $2 \mathrm{ml}$ of $25 \%$ (w/v) meta-phosphoric acid. All samples were frozen and stored for later analysis.

For VFA and $\mathrm{Cr}$ measurements, the frozen ruminal fluid samples were thawed and centrifuged at $30,000 \mathrm{x} \mathrm{g}$ for $20 \mathrm{~min}$. Concentrations of total and individual VFAs (acetic, propionic, butyric, valeric and isovaleric acids) in ruminal fluid were measured using gas chromatography (model 5890, Hewlett-Packard, Avondale, PA) as described by Vanzant and Cochran (1994). Total VFA concentration in the rumen was calculated from the average of 2 day samples of the ruminal fluid.

Concentrations of $\mathrm{Cr}$ in the ruminal fluid samples were measured using an atomic absorption spectrophotometer. According to the model proposed by Faichney (1993), the flow rate of ruminal fluid is the slope of the marker disappearance from the ruminal fluid compartment calculated by linear regression analysis. The natural logarithm of $\mathrm{Cr}$ concentration was regressed Gainst sampling time to obtain a slope for estimating the flow rate, where as the ruminal fluid volume was obtained by extrapolation of the regression line to zero time.

\section{Particle size distribution in rumen digesta and faeces}

Particle size distribution of ruminal digesta and faeces samples was determined by wetsieving, in accordance with the procedures of Poppi et al. (1980). The sieve sizes (length of side of square hole) were 4.0, 2.0, 1.0, 0.5 and 0.25 mm (Endecotts test sieve shaker, Endecotts Ltd., London). Additionally, the fine particles passing the bottom sieve were estimated after collection by centrifugation of fluid in which the fine particles were allowed to settle overnight, followed by removal the supernatant by suction. The particles retained on sieve of $1 \mathrm{~mm}$ or greater was defined as the large particle fraction.

\section{Statistical Analysis}

Statistical differences of parameter mean values measured between the two breeds were evaluated by the student's $t$-test analysis. 


\section{RESULTS}

Digestibility, Rumen Digesta (Fluid and Particulate matter) and its kinetics

Apparent digestibility of dry matter, organic matter, total fiber and lignin the diet were significantly higher in $\mathrm{G}$ than those in $\mathrm{S}(\mathrm{P}<0.05)$ (Table 1), where as daily organic matter intake of wheaten chaff by both species was not significantly different, $49.1 \pm 4.2 \mathrm{~g} / \mathrm{kg} \mathrm{BW}^{0.75} / \mathrm{d}$ in $\mathrm{G}$ and $52.4 \pm 5.4 \mathrm{~g} / \mathrm{kg} \mathrm{BW} \mathrm{BW}^{0.75} / \mathrm{d}$ in $\mathrm{S}(\mathrm{P}>0.05)$. These present results were similar to those reported in many published papers (Tolkamp and Brouwer, 1993).

The higher digestibility of wheaten chaff hay in $G$ could apparently be attributable with the flow rate of digesta (fluid and particle) along the digestive tract. The mean value of daily ruminal fluid volume in either $\mathrm{S}$ or $\mathrm{G}$ was not significantly different, which was $15 \%$ of body weight (Table 1). The mean value of outflow rate of ruminal fluid per unit of metabolic BW was $34 \%$ higher significantly in $\mathrm{S}$ compared to that of $\mathrm{G}(\mathrm{P}<0.01)$, which was resulted in $20 \%$ greater MRT of fluid in $\mathrm{G}$ than in $\mathrm{S}(\mathrm{P}<0.05)$.

Distribution of particulate matter in the rumen (Table 2) indicated that the small particles $(<1 \mathrm{~mm})$ and large particles $(>1 \mathrm{~mm})$ in the rumen of $\mathrm{S}$ were $74.3 \%$ and $25.7 \%$ respectively, which were significantly different $(\mathrm{P}<0.05)$ with those in the rumen of $\mathrm{G}, 83.2 \%$ and $16.8 \%$ respectively.
However, no species differences regarding particles size in the faeces, the most particles (>99.0\%) were smaller than those retained on 1mm sieve.

\section{VFA production in the rumen}

VFA production in the rumen of both species fed wheaten chaff was primarily acetic acid. However, the ratio acetic/propionic acid was higher in $\mathrm{S}$ than that in $\mathrm{G}$, and the proportions of butyric, valeric and isovaleric were higher in $\mathrm{G}$ than in S. Since energy content per mol of propionic, butyric, valeric or isovaleric acids was higher compared to that of acetic acid, hence the amount of energy obtained per unit of organic matter digested was also higher in $\mathrm{G}$ than in $\mathrm{S}$.

\section{DISCUSSION}

The results indicated that apparent digestibility of rice straw chaffed hay (included dry matter, organic matter, fiber and lignin) by $G$ was significantly higher compared with that by the $\mathrm{S}$. This superiority of $\mathrm{G}$ may be attributable with several factors as indicated by the results of this experiment, including (a) flow rate of digesta (fluid and particulate matter) and ruminal pool size, (b) particle size distribution, and (c) rumen environment.

Retention time of digesta in the rumen was markedly higher in $\mathrm{G}$ than that in S. It allows a

Table 1. Mean Values of Feed Constituent Digestibility, Ruminal Fluid Volume and its Kinetics, and Retention Time of Particulate Matter in the Rumen and along the Gastrointestinal Tract in S and G of Jeneponto Fed Rice Straw Chaffed Hay $(\mathrm{n}=4 ;$ mean $\pm \mathrm{SD})$

\begin{tabular}{lrr}
\hline & Sheep & \multicolumn{1}{c}{ Goat } \\
\hline Apparent digestibility (\%) & & \\
Dry matter & $55.4 \pm 3.43^{\mathrm{a}}$ & $59.5 \pm 2.15^{\mathrm{b}}$ \\
Organic Matter & $63.8 \pm 2.51^{\mathrm{a}}$ & $68.1 \pm 2.05^{\mathrm{b}}$ \\
$\mathrm{N}$ & $25.8 \pm 2.62^{\mathrm{a}}$ & $36.7 \pm 4.10^{\mathrm{b}}$ \\
Crude Fiber & $39.3 \pm 3.15^{\mathrm{a}}$ & $44.9 \pm 3.22^{\mathrm{b}}$ \\
Lignin & $12.2 \pm 1.80^{\mathrm{a}}$ & $20.5 \pm 1.80^{\mathrm{b}}$ \\
Rumen fluid volume (l) & $7.07 \pm 0.6^{\mathrm{a}}$ & $4.57 \pm 0.4^{\mathrm{b}}$ \\
ml / kg B W & $147.9 \pm 10.8^{\mathrm{a}}$ & $148.9 \pm 8.4^{\mathrm{b}}$ \\
Outflow Rate of Rumen fluid & & \\
\% / h & $9.3 \pm 0.1^{\mathrm{a}}$ & $7.8 \pm 0.3^{\mathrm{b}}$ \\
ml / h & $665.5 \pm 28.7^{\mathrm{a}}$ & $360.7 \pm 21.4^{\mathrm{b}}$ \\
ml / kgB W & $37.1 \pm 4.0^{\mathrm{a}}$ & $27.7 \pm 2.9^{\mathrm{b}}$ \\
Mean Retention Time of ruminal fluid (h) & $10.75 \pm 1.1^{\mathrm{a}}$ & $12.82 \pm 1.2^{\mathrm{b}}$ \\
\hline Different supers cript at the s ame row indicates differ significantly (P<0.05) by $t$-test
\end{tabular}


Table 2. Particle Size Distribution (\% Particulate Dry Matter Retained on Sieve Size) in the Rumen Digesta and Faeces of S and G Fed Rice Straw Chaffed Hay

\begin{tabular}{cccc}
\hline \multicolumn{2}{c}{ Sieve size } & Sheep & Goat \\
\hline Ruminant Digesta & & & \\
& $<1.0$ & $74.3^{\mathrm{a}}$ & $83.2^{\mathrm{b}}$ \\
& $>1.0$ & $25.7^{\mathrm{a}}$ & $16.8^{\mathrm{b}}$ \\
& 4 & 7.8 & $16.8^{\mathrm{b}}$ \\
2 & 7.5 & 5.2 \\
& 1 & 10.4 & 8.3 \\
& 0.5 & 15.7 & 17.4 \\
& 0.25 & 24.6 & 27.9 \\
Faeces & $<0.25$ & 34 & 37.9 \\
& $<1.0$ & & \\
& $>1.0$ & 99.5 & 99.7 \\
4 & 0.5 & 0.3 \\
2 & - & - \\
1 & 0.1 & 0.1 \\
& 0.5 & 0.4 & 0.2 \\
& 0.25 & 12.4 & 9.5 \\
& $<0.25$ & 45.7 & 49.6 \\
\hline
\end{tabular}

Different superscript at the same row indicates differ significantly $(\mathrm{P}<0.05)$ by $t$-test

longer exposure of particulate matter to microbial activity in the rumen, and therefore it resulted in a greater digestibility in G. However, if the particulate matter is retained longer in the rumen of $\mathrm{G}$, it will depress feed intake relative to metabolic body weight than S, which was not happened in this experiment. A possibility to explain these contradiction results is that fermentation rate in the rumen of $G$ was higher than in S. Therefore, overall elimination organic material from the rumen of both species was about the same, which then resulting in a similar feed intake. This explanation is supported by higher production of VFA in rumen of $\mathrm{G}$ which have the same rumen volume relatively to $S$.

In addition to differences in microbe species and population in the rumen of both species (Gihad et al., 1980; Cabrera et al., 1983), there was a possibility that $G$ has a better chewing activity than $S$, which then resulted in a greater proportion of the small particles in the rumen of $G$ than those in the rumen of S. Domingue et al. (1991b) and McSweeney and Kennedy (1992) reported that chewing during eating and rumination was longer in goats than in the sheep, which then resulted in smaller size of particles in the rumen of goats. This greater proportion of small particles in the ruminal digesta of $G$ indicated a larger surface area for the attachment of microorganisS and microbial attact (Hungate, 1966; Akin, 1976; Cheng et al., 1977).

In the present experiment only less than $0.5 \%$ of the particles in the feaces of both species were retained on a sieve larger than $1 \mathrm{~mm}$ in size (large particle). It can be interpreted that once the digesta has left the rumen, there appears to be little or no further reduction in the size of the particles (Hungate, 1966). It seem that the "critical particle size" for leaving the rumen that was found in sheep (Poppi et al., 1980) may be similar in goats. This is consisten with the results of a recent comparison of the size and distribution of digesta particles in sheep and goats (Domingue et al., 1991a).

The results of the present experiment may also be attributable with the previous study on Merino sheep and Angora Goats fed oaten chaffed hay (Rahardja, 1995) which indicated that the retention time of particulate matter was longer than the retention time of fluid in both $S$ and $G$, and presumably the differences exceed the time required to reduce the particles to a size allowing their passage from the rumen. Retention of particulate matter selectively in the rumen is commonly related to the 'bottle neck' function of the reticulo-omasum orifice (Hofmann, 1989) and 
to the more effective retention of feed particles with the bulk of the rumen content, the 'filter bed' effect (Faichney, 1993). Species differences in the kinetics of fluid outflow from the rumen suggest that there are some intrinsic factors affecting the passage, such as rumen contraction rate. However, the result of this experiment showed that species differences in retention time of particulate matter $(42 \%)$ are larger than species differences in the flow rate of rumen fluid (20\%). It suggests that one of the above mechanism, or both (i.e., 'bottleneck' and 'filter bed'), is more efficient in $G$ than in S. If so, it can be predicted that $\mathrm{G}$ are able to fill a larger amount of dry matter in the rumen than S. To support this, the ratio between DMI and average rumen volume in $\mathrm{G}$ (141 g/l) was about $18.6 \%$ higher than in $\mathrm{S}(119 \mathrm{~g} / \mathrm{l})$. Supporting this results, Gihad et al. (1980) also reported that gaots have more rumen capacity than sheep.

Hungate (1966) indicated that most fermentation takes place in the particulate matter. More over, Forsberg and Lam (1977) and Faichney (!980) found that particle-associated mocroorganism make up a major proportion $(70 \%)$ of the total microorganism in the rumen. Therefore, it may also be interpreted that a higher VFA concentration in the rumen of $G$ compared to $S$ is an indication of a higher microbial activity in the rumen of $G$, which also means a higher VFA production rate.

Species differences in individual VFA proportions indicated that fermentation processes were more efficient in $\mathrm{G}$ than in $\mathrm{S}$ (Table 3). The lower Ac/Prop ratio and higher proportion of branched or long chain VFA in G may probably be an indication of a more efficient microbial nitrogen assimilation and growth (Ishaque et al.,
1971; Tagari et al., 1977).

The higher level of valeric, isovaleric acid and presumably ammonia in ruminal fluid of $G$ compared with that of $S$ suggest that dietary protein was degraded to a greater extent in $\mathrm{G}$, either through greater feed particle breakdown by mastication or rumination or by higher proteolytic activity of the rumen microorganism.

Comparison between sheep and goats fed the same low quality diet $(4.5 \% \mathrm{CP})$, Watson and Norton (1982) reported that amonia concentration was $43 \mathrm{mg} / \mathrm{L}$ in ruminal fluid of sheep and 106 $\mathrm{mg} / \mathrm{L}$ in ruminal fluid of goat. Domingue et al (1991b) found that rumen amonia level below 50 $\mathrm{mg} / \mathrm{L}$ was to depress microbial activity in the rumen, as presumably occurred in S. Additionally, goats have also been found to have higher rate of salivary secretion rate (Seth et al., 1976; Domingue et al., 1991c), and high rumen amonia concentration could be maintained by a greater urea recycling to the rumen either by salivary secretion or diffusion across the rumen wall (Houpt and Houpt, 1968; Nolan, 1993), which were considerably higher in goats than in sheep fed low quality roughge. The increase in salivary secretion rate is not only to provide nitrogen for fermentation in the rumen, but also to aid in mastication of coarse and fibrous diets. Therefore, the higher levels of rumen ammonia in goats may presumably be the major reason for higher fiber digestion (Griswold et al., 2003). A similar indication has also been shown by Holstein heifer fed hig fiber diet (Marini and Amburgh, 2003).

The lower Ac/Prop ratio in $G$ was presumably also associated with a lower autflow rate of fluid from the rumen in comparison with $S$, which is an indication of a close relationship between fermentation process and fluid kinetics

Table 3. Mean Values of Total VFA Concentration and Molar

Proportions of Acetic, Propionic, Butyric, Valeric and Iso-valeric

Acids in the Rumen of $S$ and $G$ fed Rice straw Chaffed Hay

$(\mathrm{n}=4$; mean $\pm \mathrm{SD})$

\begin{tabular}{lcc}
\hline & Sheep & Goat \\
\hline Total VFA (mMol / l) & $118.57 \pm 11.43^{\mathrm{a}}$ & $133.84 \pm 12.30^{\mathrm{b}}$ \\
Molar percentage of total & & \\
Acetic acid (C2) & $74.24 \pm 5.73^{\mathrm{a}}$ & $67.26 \pm 4.73^{\mathrm{b}}$ \\
Propionic acid (C3) & $16.18 \pm 1.11^{\mathrm{a}}$ & $20.58 \pm 1.89^{\mathrm{b}}$ \\
Butyric acid (C4) & $7.89 \pm 0.45^{\mathrm{a}}$ & $9.17 \pm 0.50^{\mathrm{b}}$ \\
Valeric \& Isovaleric acids (C5) & $1.69 \pm 0.31^{\mathrm{a}}$ & $2.99 \pm 0.42^{\mathrm{b}}$ \\
Acetatic / Propionic ratio & 4.6 & 3.3 \\
\hline
\end{tabular}

Different superscript at the same row indicates differ significantly $(\mathrm{P}<0.05)$ by $t$-test 
from the rumen (Ishaque et al., 1971).

The advantages of having a lower ratio acetate/propionate ratio and a higher proportion of long or branched VFAs are : (1) propionic acid is a procusor for glucose by gluconeogenesis (Leng, 1970), which is essential for diets containing low energy and amino acids, such as rice straw; (2) VFAs produced have higher energy content.

\section{CONCLUSION}

It can be concluded that the higher rates of digestion of rice straw chaffed hay in $\mathrm{G}$ compared with $S$ are particularly attributable to a longer retention time of digesta (fluid and particulate matter), although further studies are required to reveal and to conform some speculations made above in the discussion.

\section{REFERENCES}

Akin, D.E. 1976. Ultrastructure of rumen bacterial attachment to forage cell wall. App.Environ.Microbiol. 31:562-568.

Binnersts, W.T., A.T.H., Van't Klooster and A.M. Frens. 1968. Soluble chromium indicator measured by atomic absorption in digestion experiment. Vet.Rec. 82:470.

Brosh, A., I. Chosniak, A. Tadmor and A. Shkolnik. 1986. Infrequent drinking, digestive effeciency and particle size of digesta in Black Beouin goats. J.Agric.Sci. 106:575-579.

Brown, L.E. and W.L. Johnson. 1982. Product of digestion and metabolism in goat and sheep feed varying levels of wheat straw. Proc. $3^{\text {rd }}$ Int.Conf. on Goat Prod. Disease, Tucson, Arizona, USA., 10-15 January 1982. P. 362.

Cabrera, R., P. Villarroel, E. Vial and A. Castillo. 1983. Rumen fermentative activity in the goat and sheep. S. Afr. J.Anim. Sci. 13:213215.

Cheng, K.J., D. E. Akin and J.W. Costerton. 1977. Rumen bacteria : interaction with dietary components and response to dietary variation. Fed. Proc. 36:193-197.

Devendra, C. 1989. Comperative aspects of digestive physiology and nutrition in goats and sheep, In : Ruminant Physiology and Nutrition in Asia (C. Devendra and E. Imaizumi, eds). Jap. Soc. Zootech. Sci., Sendai, Japan. P. 45 - 60

Domingue, B.M.F., D.W. Dellow, P.R. Wilson and
T.N. Barry. 1991a. Comparative digestion in deer, goats and sheep. NZ. J. Agric. Res. 34:45-53.

Domingue, B.M.F., D.W. Dellow, P.R. Wilson and T.N. Barry. 1991b. The effeciency of chewing during eating and rumination in goat and sheep. Br. J. Nut. 65:355-363.

Domingue, B.M.F., D.W. Dellow, P.R. Wilson and T.N. Barry. 1991c. Nitrogen metabolism, rumen fermentation, and water absorption in red deer, goats and sheep. NZ. J. Agric. Res., 34:391-400.

Doyle, P.T., J.K. Egan and A.J. Thalen. 1984. Intake, digestion and nitrogen and sulfur retention in Angora goats and Merino sheepfed herbage diets. Aust. J. Agric. Anim. Husb. 24:165-169.

Faichney, G.J. !980. Measurement in sheep of the quantity and composition od rumen digesta and of the fractional outflow rates of digesta constituents. Aust. J. Agric. Res. 31:11291137.

Faichney, G.J. 1993. Digesta flow, In : Quantitaive Aspects of Ruminant Digestion and Metabolism (J.M. Forbes and J. France, eds). C.A.B. International, Univ. Press, Cambridge. P. 53-85

Focant, M., M. Vanbelle, and S. Godfroid. 1986. comperative feeding behavior and rumen physiology in sheep and goats. World Rev.Anim.Prod. XXII : 89-95.

Forsberg, C.W. and K. Lam. 1977. Use of 5triphosphate as an indicator of the microbe biomass in rumen content. Appl. Environ. Microbiol. 33:528-537.

Gihad, E.A., T.M. El-Bedawi and A.Z. Mehrez. 1980. Fiber digestibility by goat and sheep. J. Dairy Sci. 63:1701-1706.

Goering H.K. and P.J. Van Soest. 1970. Forage fiber analysis (apparatus, reagents, procedures and some applications). Agric. Handbook no. 379. Washington D.C., US DA.

Griswold, K.E., G.A. Apgar, J. Bouton and J.L. Firkins. 2003. Effects of urea infusion and ruminal degradable protein concentration on microbial growth, digestibility and fermentation in continuous culture. J. Anim. Sci. 81:329-336.

Hofmann, R.R. 1989. Evolutionary steps of ecophysiologycal adaptation of ruminants : a comparative view of their digestive system. Oecology 78:443- 457.

Houpt, T.R. and K.A. Houpt. 1968. Transfer of 
urea nitrogen across the rumen wall. Am. J. Physiol. 214:1296-1303.

Howe, J.C., T.N. Barry and A.I. Popay. 1988. Voluntary intake and digestion of gorse (Ulex europaeus) by goats and sheep. J. Agric.Sci. Camb. 111:107-114.

Hungate, R.E. 1966. The Rumen and its Microbes. Academic Press, London, UK.

Huston, J.E., B.S. Engdahl and K.W. Bales. 1988. Intake and digestibility in sheep and goats feed three with different levels of supplemental protein. Small Rumin. Res. 1: 81-92.

Ishaque, 1., P.C. Thomas and A.J.F. Rook. 1971. Relationship between the pattern of ruminal fermentation and the flow to the duodenum of sheep receiving a diet of barley, flake maize and ground hay. Proc. Nutr. Soc. 30: 1A-2A.

Leng, R.A. 1970. Formation and production of volatile fatty acids in the rumen. In: Physiology of Digestion and Metabolism in Ruminant (A.T. Phillipson, ed). Oriel Press, UK. P. $406-421$.

Marini, J.C. and M.E. Amburgh. 2003. Nitrogen metabolism and recycling in Holstein heifers. J. Anim. Sci. 81:545-552.

McGregor, B.A. 2000. Recent advances in marketing and product development of mohair and cashmere. Proc. $7^{\text {th }}$ Int.Conf. on Goats, Tour, France 15-18 May 2000. Book II, pp. $631-637$.

McSweeney, C.S. and P.M. Kennedy. 1992. Influence of dietary particle size on chewing activity and reticulo-ruminal motility in goats and sheep fed wheaten (Triticum aestivum) hay. Small Rumin. Res. 9:107-115.

Nicol, G.R. and J.L. Corbett. 1971. Equipment for hourly feeding of sheep. Lab. Pract. 20:727.

Nolan, J. 1993. Nitrogen kinetic, In : Quantitaive Aspects of Ruminant Digestion and Metabolism (J.M. Forbes and J. France, eds). C.A.B. International, Univ.Press, Cambridge. P. $123-143$.
Poppi, D.P., B.W. Norton, D.J. Minson and R.E. Hendricksen. 1980. The validity of the critical size theory for particles leaving the rumen. J. Agric. Sci., Camb. 99 :275-280.

Rahardja, D.P. 1995. Rumen Fluid dynamic in Marino sheep and Angora goats fed oaten chaffed hay and free access to salt water, in 'Studies on water and salt metabolism in Sheep and Goats', PhD Dissertation. The University of New England, Armidale, Australia.

Raun, N.S. and W. Burroughs. 1962. Suction stainer technique in obtaining rumen fluid samples from intact lamb. J.Anim.Sci. 21: 454-457.

Reid, R.L., G.A. Jung, J.M. Cox-Ganser, B.F. Rybeck and E.C. Townsend. 1990. Comperative utilization of warm- and coolseason forages by cattle, sheep and goats. J.Anim.Sci. 68:2986-2994.

Seth, O.N., G.S. Rai, P.C. Yadar and M.D. Pandey. 1976. A note on the fate of secretion and chemical composition of parotid saliva in sheep and goats. J.Anim.Sci. 46:660-663.

Tagari H., D. Ben-Ghedalia and Y. Sthern. 1977. The effect of two feeding levels containing field-cured or frozen Rhodes grass (Chloris gayana), on digestibility and rumen metabolites in sheep. J.Agric.Sci. 89:177182.

Tolkamp, B.J. and B.O. Brouwer. 1993. Statistical Review of digestion in goats compared with other ruminants. Small Rumin. Res. 11:107123.

Vanzant, E.S. and R.C. Cochran. 1994. Performance and forage utilization by beef cattle receiving increasing amount of alfafa hay as a supplement to low quality, tallgrasspraire forage. J. Anim. Sci. $72: 1059-1067$.

Watson, C. and B.W. Norton. 1982. The utilization of Pangola grass hay by sheep and Angora goats. Proc.Aust. Soc. Anim. Prod. 14:467-470. 